\title{
Introduction to special issue: Gender, knowledge production and knowledge work
}

This special issue explores diverse forms of knowledge work that reconfigure and or reproduce gender relations and gender ideologies in organizations whose central mandate includes knowledge production. Knowledge about gender is produced by women's organizations, public bodies, corporations and international institutions as they engage in efforts to shape discourses, policies and practices on gender equality. We focus on the institutions whose special purpose is to produce knowledge in a usable form for others. These include universities and academic disciplines, but also new and old media, cultural and policy-centred networks and profit-making information managers.

Our contributors analyse the implicit gender knowledge underpinning human action as well as the specific, explicit, new knowledge about gender often called gender expertise (Cavaghan, 2017; Ferguson, 2018). In the former case, gender slips silently into organizational knowledge production practices, where labour is recognized, divided and commodified, usually to the detriment of women in the system. In the latter, gender relations are brought to the surface of organizational knowledge work. Here, contestations over expertise engage ideas about gender inequality and interpretations of women's presence, roles, action, interests, needs, rights and capacity for voice. As gender knowledge becomes more explicit, women's authority over naming, describing and interpreting evidence of inequality is itself articulated, contested, co-opted and resisted. Since knowledge about gendered knowledge work is so fundamental to the operation of institutions like media, corporations and universities, it is not surprising to find that the struggles over implicit and explicit gendered knowledge practices engage political authorities who at times support and at times undermine the work of gender experts.

Is knowledge power? Scholars working in interpretative traditions and the sociology of knowledge suggest that every form of practical knowing - be it everyday knowledge, expert knowledge and popularized knowledge - is based upon a specific, often tacit and unconscious, form of gender knowledge (Cavaghan, 2017; Young \& Scherrer, 2010). As an analytical concept, tacit gender knowledge enables the examination and comparison of competing gendered meanings in processes and action. It is at its core a critique of the apparent gender neutrality of knowledge and it allows for the identification of specific sites and forms of gendered power relations. Applying such a concept especially helps to theorize the role of resistances and opposition in the dynamics, determinants and impacts of gender and sexual politics (Kuhar \& Paternotte, 2017; Verloo, 2018). Several of the contributions to this issue highlight just how actors, interests and institutions can work to block an influx of alternative gender knowledge and thus to maintain some specific rejection of, non-engagement with or institutionalized ignorance of gendered processes. Situating knowledge in networks of institutional power, recognizing tacit knowledge as gendered and looking at gendering knowledge as demanding organizational work offers insight into the uneven progress of gendered social change.

In this special issue, higher education, diverse media and state politics are examined as contexts for the production, reworking and dissemination of knowledge and are approached as gendered organizational domains that create challenges and opportunities for female workers, organizational gender equality practices and feminist forms of knowing. In making sense of what gendered knowledge is, how it is produced and when and how it is applied to transformative effect, the politics of discourse have their effects in and through these specific institutional contexts (Lombardo, Meier, 
\& Verloo, 2010). For example, higher education is especially concerned with contestation over 'excellence' and state politics revolve often around 'austerity'; in both domains, knowledge about gender and gender equality circulates in public debates that promote a business case for greater gender equality at the expense of more transformative feminist knowledge about intersectional inequalities (Bassel \& Emejulu, 2017; Cullen \& Murphy, 2018).

When combined with a focus on systems of governance and techniques of governmentality, studies of discourses can reveal the tacit gendered norms and meanings at the core of gender inequality (Kantola \& Lombardo, 2017, pp. 7-8). Considerations of affect (Ahmed, 2004) and emotion (Ferree \& Merrill, 2000; Jasper, 2018) in making and unmaking knowledge increasingly feature in studies of politics and governmentality, especially in gendered critiques (Hemmings, 2012; Lorey, 2015). While understanding organizational power in terms of affect is new, research on work and organizations has long included feelings in the study of gendered work experience. This is exemplified in studies of knowledge workers (Acker, 1990; Hochschild, 1983; Walby, 2011; Williams, 2013); gendered hierarchies of knowledge and gendered workplaces in technology (Harvey \& Fisher, 2015; Wajcman, 2010); and in media and creative industries (Gill \& Scharff, 2011; Mayer, 2011).

Several of the contributions in this issue direct attention to the emergence of new forms of knowledge in the organization of work practice, both historically and today. Circuits in which knowledge can be amassed, assessed and disseminated are built organizationally on gendered foundations. Gendered actors work in these systems, and may unconsciously reproduce them, as in the development of one of the earliest forms of commodified information technology in the media landscape, the press clipping bureau, or build consciously gendered structures of resistance, like the networks of women organizational scholars contesting the marginalization of feminist knowledge in business schools. Feminist scholarship on the politics of feminist knowledge transfer and the role of gender expertise in international development (Prügl, 2015) highlights tensions in gender mainstreaming (Cavaghan, 2017; Roberts, 2015) and higher education governance (Bustelo, Ferguson, \& Forest, 2016; Deem, 2010). Examining organizational contexts understood as sites of epistemic power exposes how knowledge work itself has a role in the maintenance of gender relations, structures, practices and inequalities. In the systems of higher education and mass media, feminist scholars have been advancing formal policies that will challenge their gendered inequalities, and several of the contributors offer important insights into precisely which kinds of knowledge about gender are incorporated and resisted. How statistical, experiential, reflexive, collective forms of knowledge differ in what they can and cannot reveal is the focus of these articles.

While distinctions between feminist and gender knowledge can be less than satisfactory, we suggest that feminist knowledge will insist on an understanding of gender inequality in structural and systematic terms and be committed to a transformation of intersectionally unequal power relations. Feminist knowledge as we see it is also situated, plural, political and contested, reflexive and a product of engagement by feminist researchers, practitioners and activists (Bustelo et al., 2016; Stachowitsch, 2018). The fate of feminist knowledge as it enters institutions organized on other principles is a key concern in these accounts, especially for those scholars who focus on the ways feminist ideas combine with corporate logics (Fraser, 2016) or racialized governmentality (Bumiller, 2013). The potential for co-optation rises as feminists access authority within institutions, but insider access and alliances are also invaluable assets in securing, using and validating feminist knowledge.

With this broad agenda in mind, several of our contributors offer interventions in the practical politics of knowledge, and specifically higher education as a site of knowledge production and work. Kate Huppatz, Katherine Sang and Jemina Napier study academic women who are mothers and their experiences of maternity and flexible work policies in the neoliberal university. They unpack the kinds of knowledge generated in experiencing conflict between organizational leave policies and the demands of academic labour. Their view of the ubiquitous term 'work-life conflict' decentres the formal policies and highlights how competitive logics work on mothers to internalize marketized notions of academic performance and constrain their agency to refuse engagement with academic work while on leave. Drawing on Foucault and Bourdieu, they suggest that processes of self-responsibilization and individualization reinforced by managerial discourses work to undermine leave entitlements and erase boundaries between leave and work. 
As an earlier study of women's entrepreneurial subjectivity found, organizational demands for forms of neoliberal subjectivity are linked to women's anxiety, depoliticization, repudiation of vulnerability and internalized competition (Gill \& Scharff, 2011). Huppatz and her co-authors show here that similar processes operate in a university in the face of supposed gender equality initiatives. Their qualitative interviews with mothers on leave point to how academic organizations and their representatives misrecognize in wilful ways what social reproduction demands. Of specific merit is a focus on academic mothers' understanding of the complex forms of compensatory 'work' and trade-offs demanded for their survival and success in academia. Self-responsibilization, and the associated reflex to pathologize one's own performance and moralize productivity, is a deeply internalized knowledge that produces forms of ambivalence and unknowing about the structural sources of gender inequality in higher education. The article highlights the awareness that academic mothers have of gender inequality in academia and their conscious strategies to navigate entitlements and self-regulate their embodiment as mothers, and so lends needed complexity to more broad-stroke characterizations of neoliberalized female workers as seamlessly in sync with entrepreneurial self-projects.

Rather than focusing on quandaries produced for individuals by marketization, Sally Jones, Angela Dy and Natalia Vershinina detail processes of feminist knowledge production that offer collective resistance to the ghettoization and marginal status of feminist expertise. Using the case of international business and management studies in which they participate, they propose that network formation has proved an important strategy for challenging how universities ignore knowledge claims of feminist scholars. A specific merit of their research is the combination of insights from work on gender and inequality regimes with the science and technology studies approach to knowledge regimes. The authors advance the concept of 'gender knowledge regimes' to better understand the dynamics of subordination and discrimination experienced by gender scholars and to afford analytical space to assess forms of resistance.

They take the formation and development of the UK-based Gender and Enterprise Network (GEN), to which they belong, as evidence of resistance and a form of transgressive practice that not only enhances the professional networks and career progression of members, but also supports the deepening and mainstreaming of feminist expertise. In their view, GEN illustrates the capacity of gender scholars to subvert existing knowledge hierarchies and associated practices by articulating an alternative gender knowledge regime based on broad feminist principles of transdisciplinarity, collectivism and equality. This work offers a valuable account of how feminist knowledge production through networks can act as refuge and resource for gender scholars in masculinized disciplines. In recounting how female academics in management studies work to change spaces ambivalent at best to critical feminist knowledge, the authors add to efforts to dispel simple constructions of neoliberal feminism (Fraser, 2016) and the supposed duality between 'pure' and 'co-opted' feminist knowledge (de Jong \& Kimm, 2017; Eschle \& Maiguashca, 2018; Halley, Kotiswaran, Rebouché, \& Shamir, 2018; Newman, 2013). Adding to research on the fate of feminist knowledge claims when engaging with powerful organizational contexts (Bustelo et al., 2016; Prügl, 2015; Stachowitsch, 2018), this auto-ethnographic network study suggests some particular conditions under which such knowledge might be integrated into broader discourses and policies on gender and gender equality.

Also focused on the collective work being done by feminist academics to advance gender equality within specific disciplines, Kathrin Zippel and Myra Marx Ferree look at the STEM (science, technology, engineering and mathematics) disciplines in the United States. The National Science Foundation, the state agency that is the primary funder of basic research in these disciplines, has used its power to shape the knowledge production process in order to support interventions designed to produce new knowledge about how gender equality can be fostered in American colleges and universities. Zippel and Ferree's account focuses on the challenges and opportunities inherent in the funding structure, programme design, participant interests and emergent networks of this ADVANCE programme. They highlight the evolution of the programme over time as an example of organizational learning spurred by feminist engagements in its knowledge production process, but also describe the structural obstacles that confront feminist actors trying to do transformative knowledge work in and across the academic organizations they inhabit. By systematically delineating the aims and practices of ADVANCE at different levels, they add nuance to positive and negative assessments of ADVANCE's effectiveness as a change agent for gender equality. Since ADVANCE aims to further gender equality both by applying gender knowledge to make data-driven, research-informed change in universities 
and by producing new generalizable scientific knowledge about gendered organizations, this programme confronts the differential value that academic organizations give to these kinds of knowledge work.

These valuations matter in understanding how initiatives aimed at addressing gender inequality take different forms when confronted with existing internal disciplinary and knowledge hierarchies. Zippel and Ferree argue that the context of knowledge production on gender equality is shaped by the intensive competition between US universities, the superior status of scientific knowledge compared to applied research and organizational managerialism as a condition of modern higher education. Of particular consequence is their emphasis on the tensions that exist between the programme's aims and its practices. ADVANCE navigates these challenges and evolves over time to produce gendered knowledge about inequalities, authenticate feminist knowledge of organizations and challenge the epistemic hierarchy between fundamental and applied knowledge. The authors offer important insights into how ADVANCE has been flexible enough to endure and to support gender knowledge transfer, despite the contested context within which it operates and the forms of power attendant to high prestige institutions of knowledge production. Their findings will add to current scholarly and policy-oriented discussions about gender knowledge transfer in academic institutions worldwide, including current controversies surrounding the ATHENA SWAN certification programme in the European Union, providing a map to navigate institutional and political processes at play.

Where feminist knowledge has found a foothold and form of transmission in the cases of GEN and ADVANCE, Johanna Kantola, Anna Elomäki, Anu Koivunen and Hanna Ylöstalo offer an account of the struggles and setbacks faced by feminist academics engaging with policymakers, politicians and more broad public discourse in a supposedly woman-friendly Nordic state. Shifting our attention to the outreach of academic feminism into national governance in Finland, this article focuses on the role of what has been termed governance feminism in making visible the gendered implications of austerity. In this contribution, the authors reflect on their own participation in a media campaign to use feminist knowledge to intervene in debates on the economic crisis and austerity provoked by a new conservative government. Drawing on the concept of affect and specifically the 'affective virtuosity', the authors confront much-debated issues about how close to power feminist activists can be before processes of co-optation disable their capacity for critique. In a chronological account of academic feminist protest and engagement with the Finnish state, the authors offer a reflection on the possibilities and constraints for feminist knowledge production and diffusion, and the influence of the taken-for-granted idea that the Finnish state is 'woman-friendly' in public debate in the context of austerity and neoliberal governance.

Finnish academic feminists in this account employed their elite, expert position as they aimed to influence government policy. The focus here is on the strategies they adopted and the forms of negotiation required as they engaged in political debates where they had influence and where they failed to do so. The novelty in this assessment lies in part with their focus on the role of affect in feminist knowledge production and diffusion, for instance, showing how politicians drew on discourses of outrage and incredulity to deflect feminist charges. Notably, the analysis presented deepens our understanding of the trade-offs that operate within forms of governance feminism, where forms of emotion, in this context ambivalence, complicate the options available to feminist scholars in encounters with politicians and policymakers. Here the effort to outline the tensions, progress and failures of feminist knowledge transfer in strategic and epistemic terms is instructive for those aiming to capture how oppositional forces to feminism work in subtle and more direct ways (Verloo \& Paternotte, 2018). Identifying the role of feminist knowledge and political opposition in confronting a broader state and societal project against social justice and equality also resonates with burgeoning research on forces including populism, illiberalism and de-democratization in Europe and beyond (Kuhar \& Paternotte, 2017; Verloo, 2018). In the context of specific state efforts to erase the academic study of gender and gender inequality (in Hungary, Italy, France and the United States) the fate of feminist knowledge is of particular import.

How and when different forms of gender knowledge, including feminist knowledge, gain traction or are sidelined is also central to the article by Doris Eikhof, Jack Newsinger, Daria Luchinskaya and Daniela Rudloff, who examine initiatives to diversify and improve gender representation in the UK media sector. Drawing on a knowledge ecology framework, they pose the question of what knowledge about gender equality is made visible and actionable in the UK 
screen industries. This study offers a much-needed empirical foundation for assumptions about the normative and epistemic barriers to the successful application of gender equality policies. Through a systematic assessment of policy approaches to diversity in media they show how gender knowledge production for the UK screen sector operated with reductionist understandings of gender and gender inequality, and presented gender inequality as something that needed evidencing rather than changing. They also found that gender knowledge was circulated in two relatively distinct circuits, a policy- and practice-facing one focused on workforce statistics and a more heterogeneous and critical academic one. Identifying such circuits of knowledge circulation adds to understanding how definitions and conceptualizations of gender and gender inequality can be employed to either disable or reproduce mechanisms of ongoing inequality. By outlining how key aspects of gender inequality in the UK screen industry remained invisible, and thus less actionable, the authors present a case for how more intersectionally diverse gender knowledge production matters for practical change. This work also suggests research opportunities exist to trace the knowledge circuits differentially advancing and retarding specific forms of gender knowledge in other industries, professional bodies and state policy systems. Their knowledge ecology framework can reveal how methodologies in part manifest the very social realities they claim to measure or represent.

Like the above-mentioned articles on ADVANCE and on Finnish policy debates, this article draws attention to how specific forms of quantifiable research are constructed as meritorious, sought by policy-making actors and available for objective assessment of social problems. They also identify how the value of different kinds of evidence is linked to the value of specific actors in particular institutional positions. They stress that state and corporate actors tend to commission research that merely documents gender inequality in organizational contexts, rather than incorporating knowledge based on a structural critique or an intersectional assessment. There appear to be strong similarities across these academic, policy, media organizational contexts in how market and state actors promote instrumentalist, human capital and depoliticized versions of gender knowledge to gain legitimacy and leave institutional practices and discourse untroubled.

Implicit gender knowledge about work is still built on older gender tropes about women's unique capabilities, soft skills and essential qualities as Daniel Hubener's innovative assessment of the development of information processing work reveals. Hubener draws on media accounts of the emergence of the press clippings industry in late $19^{\text {th }}$ into the mid- $20^{\text {th }}$ century to show how knowledge was processed as specific commodified bits of information long before computers entered the world. Gendered definitions and devaluations of work tasks and bodily abilities constructed women as machine-like and kept their wages low, even as their skills were essential to this early form of industrial-scale, commodified information processing. Relating scholarship on gender and organizations to that on knowledge production as work, Huebner offers a historically rich account of embodied knowledge, tasks stratified by gender and ideological definitions of skill. In press clipping bureaus, young women manually read and sorted thousands of newspaper articles into parcels of keyword-indexed information for the use of paid subscribers, thus becoming literally information processors. Huebner highlights how the concept of knowledge work needs to be separated from dependence on contemporary technologies and labour conditions. The article also challenges assumptions about information processing as knowledge work, by showing how it is older, more fundamentally gendered and more expansive than is typically recognized. Hubener's social historical focus also reminds us of the merit of looking back to better understand the roots and branches of gendered work, organization and knowledge production.

This issue is unusual in that methodologically, the articles by Zippel and Ferree, Jones et al. and Kantola et al. rely in part on auto-ethnographical accounts of collective action where actors engage together to introduce feminist knowledge into powerful organizational contexts. In relying on their subjective experiences, analysed in a reflexive and critical manner, the authors work to convey the complex political, affective and interpersonal networks shaping efforts by individuals, collectives and institutions to counter hostility and /or indifference to transformative feminist frameworks. The rich 'insider' accounts generated here point to the potential for feminist actors to draw on their own subjectivities. But as Eikhof et al. point out, these efforts face resistance in part grounded in the superior status accorded to gender knowledge codified in statistical and metricized terms. As these latter authors cite Ruppert, E., \& Savage, M. (2011, 
p. 11) to argue, methodologies used to create knowledge 'have relations, circulate and (re-)produce realities and have genealogies - of problems, interests, purposes - that are mutually implicated'. These complexities, they argue, need to be appreciated if we want to understand the potential of gender knowledge to facilitate social change.

For Kantola et al., feminist knowledge and methodologies hold a marginal status when compared with other quantifiable forms of evidence-based inputs in politics and policy making. Yet while in their negotiations with authorities and structures of neoliberal governance, they see co-optation of feminist knowledge and its methodologies of production, they also, like Zippel and Ferree, draw attention to possibilities for positive change. Qualitative interviews, social historical, documentary and auto-ethnographic approaches are used in this issue to great effect. By showing how gender knowledge production, diffusion and dissemination is a contingent and contested terrain, the authors employ feminist critical knowledge work in their research to produce and convey new insights about the material, symbolic, affective experiences of gender. These are lived and reflexively analysed in ways that can spur further research on gender and its intersections with other inequalities across many work and organizational contexts, present, past and future.

\section{ORCID}

Pauline Cullen (D) https://orcid.org/0000-0002-1050-9842

Myra Marx Ferree (D) https://orcid.org/0000-0002-8070-6569

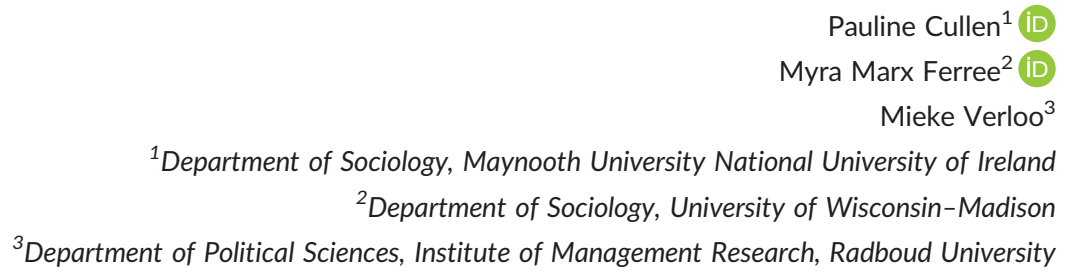

Correspondence

Pauline Cullen, Department of Sociology, Auxilia Building North Campus, Maynooth University National University of Ireland, Maynooth,

County Kildare, Ireland.

Email: pauline.cullen@mu.ie

\section{REFERENCES}

Acker, J. (1990). Hierarchies, jobs, bodies: A theory of gendered organizations. Gender \& Society, 4(2), 139-158. Retrieved from http://www.jstor.org/stable/189609. https://doi.org/10.1177/089124390004002002

Ahmed, S. (2004). The cultural politics of emotion. Edinburgh, UK: Edinburgh University Press.

Bassel, L., \& Emejulu, A. (2017). The politics of survival. Minority women, activism and austerity in France and Britain. Bristol, UK: Policy Press.

Bumiller, K. (2013). Feminist collaboration with the state in response to sexual violence: Lessons from the American experience. In A. M. Tripp, M. M. Ferree, \& C. Ewig (Eds.), Gender, violence and human security: New perspectives (pp. 191-213). New York, NY: New York University Press. https://doi.org/10.18574/nyu/9780814770207.003.0008

Bustelo, M., Ferguson, L., \& Forest, M. (Eds.) (2016). The politics of feminist knowledge transfer: Gender training and gender expertise. Basingstoke, UK: Palgrave Macmillan.

Cavaghan, R. (2017). Making gender equality happen: Knowledge, change and resistance in EU gender mainstreaming. London, UK: Routledge. https://doi.org/10.4324/9781315658544

Cullen, P., \& Murphy, M. P. (2018). Leading the debate for the business case for gender equality, perilous for whom? Gender, Work and Organization, 25(2), 110-126.

de Jong, S., \& Kimm, S. (2017). The co-optation of feminisms: A research agenda. International Feminist Journal of Politics, 19(2), 185-200. https://doi.org/10.1080/14616742.2017.1299582

Deem, R. (2010). Herding the academic cats: The challenges of 'managing' academic research in the contemporary UK university. Perspectives: Policy and Practice in Higher Education, 14(2), 37-43. 
Eschle, C., \& Maiguashca, B. (2018). Theorizing feminist organizing in and against neoliberalism: Beyond co-optation and resistance? European Journal of Politics and Gender, 1(1-2), 223-239. https://doi.org/10.1332/ 251510818X15272520831120

Ferguson, L. (2018). Gender training: A transformative tool for gender equality. Basingstoke, UK: Palgrave Macmillan.

Ferree, M., \& Merrill, D. (2000). Hot movements, cold cognition: Thinking about social movements in gendered frames. Contemporary Sociology, 29(3), 454-462. Retrieved from http://www.jstor.org/stable/2653932. https://doi.org/ $10.2307 / 2653932$

Fraser, N. (2016, July-August). Contradiction of capitalism and care. New Left Review, 100.

Gill, R., \& Scharff, C. (Eds.) (2011). New femininities postfeminism, neoliberalism and subjectivity. Basingstoke, UK: Palgrave Macmillan. https://doi.org/10.1057/9780230294523

Halley, J., Kotiswaran, P., Rebouché, R., \& Shamir, H. (2018). Governance feminism: An introduction. Minneapolis: University of Minnesota Press. https://doi.org/10.5749/j.ctt2121736

Harvey, A., \& Fisher, J. (2015). 'Everyone can make games!': The post-feminist context of women in digital game production. Feminist Media Studies, 15(4), 576-592. https://doi.org/10.1080/14680777.2014.958867

Hemmings, C. (2012). Affective solidarity: Feminist reflexivity and political transformation [Special issue: Affecting feminism: Questions of feeling in feminist theory]. Feminist Theory, 13(2), 147-161. https://doi.org/10.1177/1464700112442643

Hochschild, A. (1983). The managed heart: Commercialization of human feeling. Berkeley: University of California Press.

Jasper, J. (2018). The emotions of protest. Chicago, IL: University of Chicago Press.

Kantola, J., \& Lombardo, E. (Eds.) (2017). Gender and the economic crisis in Europe. Politics, institutions and intersectionality. Basingstoke, UK: Palgrave Macmillan.

Kuhar, R., \& Paternotte, D. (2017). Anti-gender campaigns in Europe: Mobilizing against equality. London, UK: Rowman \& Littlefield.

Lombardo, E., Meier, P., \& Verloo, M. (2010). Discursive dynamics in gender equality politics: What about 'feminist taboos'? European Journal of Women's Studies, 17(2), 105-123. https://doi.org/10.1177/1350506809359562

Lorey, I. (2015). State of insecurity government of the precarious. London, UK: Verso Press.

Mayer, V. (2011). Below the line: Producers and production studies in the new television economy. Durham, NC: Duke University Press. https://doi.org/10.1215/9780822394136

Newman, J. (2013). Spaces of power: Feminism, neoliberalism and gendered labor. Social Politics: International Studies in Gender, State \& Society, 20(2), 200-221.

Prügl, E. (2015). Neoliberalising feminism. New Political Economy, 20(4), 614-631. https://doi.org/10.1080/ 13563467.2014.951614

Roberts, A. (2015). The political economy of 'transnational business feminism'. International Feminist Journal of Politics, 17(2), 209-231. https://doi.org/10.1080/14616742.2013.849968

Ruppert, E., \& Savage, M. (2011). The double social life of methods. CRESC Working Paper No. 95. Open University, Milton Keynes.

Stachowitsch, S. (2018). Beyond 'market' and 'state' feminism: Gender knowledge at the intersections of marketization and securitization. Politics \& Gender, 1-23. https://doi.org/10.1017/S1743923X18000351

Verloo, M. (2018). Varieties of opposition to gender equality in Europe. London, UK: Routledge. https://doi.org/10.4324/ 9781315625744

Verloo, M., \& Paternotte, D. (2018). The feminist project under threat in Europe. Politics and Governance, 6(3), 1-5. https:// doi.org/10.17645/pag.v6i3.1736

Wajcman, J. (2010). Feminist theories of technology. Cambridge Journal of Economics, 34(1), 143-152. https://doi.org/ 10.1093/cje/ben057

Walby, S. (2011). Is the knowledge society gendered? Gender, Work and Organization, 18(1), 1-29. https://doi.org/10.1111/ j.1468-0432.2010.00532.x

Williams, C. (2013). The glass escalator, revisited: Gender inequality in neoliberal times. Gender \& Society, 27(5), 609-629.

Young, B., \& Scherrer, C. (Eds.). (2010). Gender knowledge and knowledge networks in international political economy. Nosmos. pp.1-23 Retrieved from https://www.unikassel.de/fb05/fileadmin/datas/fb05/FG_Politikwissenschaften/ Dateien/pdf/Gender_Knowledge_and_Knowledge_Networks_in_International_Political_Economy.pdf 